\title{
Identifikasi Bidang Gelincir di Dusun Dukuh, Desa Koripan, Kecamatan Matesih, Kabupaten Karanganyar, Menggunakan Metode Geolistrik Resistivitas Konfigurasi Wenner Alfa
}

\author{
Irwan Romadon, Darsono, dan Sorja Koesuma ${ }^{*}$ \\ Program Studi Fisika, Fakultas Matematika dan Ilmu Pengetahuan Alam \\ Universitas Sebelas Maret \\ Jalan Ir. Sutami No 36A Kentingan Surakarta 57126 \\ *E-mail : sorjasan@yahoo.com
}

DOI: http://dx.doi.org/10.13057/ijap.v6i02.1892

\begin{abstract}
Slip surface identification in Dukuh, Koripan Village, Matesih Sub-district, Karanganyar District has been conducted with geoelectrical resistivity method with Wenner Alfa configuration. Data acquisitions was done on 5 sample lines. The length of each line is 75 meter. The smallest electrode spacing is 3 meter, with multiplier (n) between 1 to 5 . Two dimensional results show that slip surface in every sample lines formed by watertight wet clays material, with resistivity $8,99 \Omega \mathrm{m}$ until $13,4 \Omega \mathrm{m}$. The depth of the slip surface in each line is varies. Slip surface of the line 1 was found at a depth of 1 meter to 3,7 meter, the line 2 was found at 2 meter to 4 meter, the line 3 was found at 0,75 meter to 3,78 meter, the line 4 was found at 1,5 meter to 3,5 meter, and the slip surface of line 5 was found at 0,75 meter to 3 meter. Three dimensionals result shows that the area with high land movement was covered by sandy-clay materials.
\end{abstract}

Keywords: slip surface, geoelectric, resistivity, Wenner-Alfa, Karanganyar

\section{ABSTRAK}

\begin{abstract}
Identifikasi bidang gelincir di Dusun Dukuh, Desa Koripan, Kecamatan Matesih, Kabupaten Karanganyar telah dilakukan dengan menggunakan metode geolistrik resistivitas konfigurasi Wenner Alfa. Pengambilan data dilakukan pada 5 lintasan uji. Panjang setiap lintasan uji adalah 75 meter. Spasi elektroda terkecil yaitu 3 meter, dengan faktor pengali (n) antara 1 sampai 5. Hasil inversi 2D menunjukkan bahwa bidang gelincir di semua lintasan uji tersusun dari material lempung basah kedap air dengan resistivitas antara $8,99 \Omega \mathrm{m}$ sampai $13,4 \Omega \mathrm{m}$. Kedalaman bidang gelincir masing-masing lintasan uji bervariasi. Bidang gelincir lintasan 1 terletak pada kedalaman 1 meter sampai 3,7 meter, lintasan 2 ditemukan pada kedalaman 2 meter sampai 4 meter, lintasan 3 pada kedalaman 0,75 meter sampai 3,78 meter, lintasan ke empat pada kedalaman 1,5 meter sampai 3,5 meter, dan lintasan ke 5 pada kedalaman 0,75 meter sampai 3 meter. Hasil pemodelan 3 dimensi menunjukkan bahwa daerah dengan pergerakan tanah yang tinggi memiliki material penutup berupa lempung pasiran.
\end{abstract}

Kata Kunci: bidang gelincir, geolistrik, resistivitas, Wenner-Alfa, Karanganyar

\section{PENDAHULUAN}

Tanah longsor adalah suatu peristiwa penurunan batuan, tanah, atau material organik, dan material non-organik tertentu, akibat adanya efek dari gaya gravitasi dan juga kondisi tanah di suatu lokasi tertentu ${ }^{[1]}$. Salah satu daerah rawan longsor di Indonesia adalah Kabupaten Karanganyar. Berdasarkan data bencana tanah longsor antara tahun 2012 sampai 2015, telah terjadi 22 kali bencana longsor di beberapa lokasi di Kabupaten Karanganyar. Longsor yang terjadi mengakibatkan rusaknya rumah, bangunan dan terganggunya akses jalan. Bahkan di 
beberapa lokasi, seperti di Desa Blumbang Kecamatan Tawangmangu dan Desa Margorejo Kecamatan Jatiyoso, terdapat korban jiwa dan korban luka akibat bencana tanah longsor tersebut $^{[2]}$.

Pendugaan potensi longsor dapat dilakukan dengan banyak metode, salah satunya dengan menggunakan metode geolistrik resistivitas. Metode geolistrik resistivitas adalah metode pencitraan untuk pendugaan kondisi bawah permukaan berdasarkan sifat kelistrikan batuan, yaitu berupa nilai tahanan jenisnya ${ }^{[3]}$. Metode geolistrik dapat digunakan untuk mencari keberadaan dari bidang gelincir (slip surface) yang ada di lokasi pengujian ${ }^{[4]}$.

Bidang gelincir merupakan lapisan yang menjadi bidang gerak dari lapisan material longsoran ${ }^{[5]}$. Bentuk dan struktur bidang gelincir akan mempengaruhi pola pergerakan material longsoran yang ada di atasnya. Bidang gelincir merupakan salah satu faktor penyebab terjadinya longsor di suatu lokasi.

Pada setiap pengukuran dengan metode geolistrik resistivitas, akan diperoleh data nilai resistivitas semu. Nilai tersebut tergantung pada konfigurasi elektroda yang digunakan. Dengan mengukur nilai tegangan $\mathrm{V}$, arus I, dan mengetahui faktor geometri dari konfigurasi elektroda yang digunakan, maka nilai resistivitas semu dapat diketahui ${ }^{[6]}$. Nilai resistivitas semu bukan merupakan nilai resistivitas lapisan tanah yang sebenarnya, karena nilai resistivitas semu adalah nilai resistivitas tanah dengan anggapan bahwa bumi terdiri dari satu lapisan homogen saja ${ }^{[7]}$.Nilai resistivitas semu dapat dihitung melalui persamaan :

$$
\rho_{a}=K \frac{\Delta V}{I}
$$

dengan $\rho_{a}$ dalam Ohm meter, $K$ dalam $\mathrm{m}^{-1}, \Delta V$ dalam Volt, dan $I$ dalam Ampere ${ }^{[6]}$.

Penelitian yang dilakukan adalah penelitian bidang gelincir dengan menggunakan metode geolistrik resistivitas dengan tujuan untuk mengetahui struktur bidang gelincir, kedalaman bidang gelincir, dan dugaan daerah dengan pergerakan tanah yang tinggi di lokasi penelitian. Konfigurasi elektroda yang digunakan yaitu konfigurasi Wenner Alfa. Konfigurasi Wenner alfa pasangan elektroda arus dan elektroda tegangan memiliki sebuah titik tengah utama dan jarak antara elektroda-elektroda yang berdekatan adalah sama.

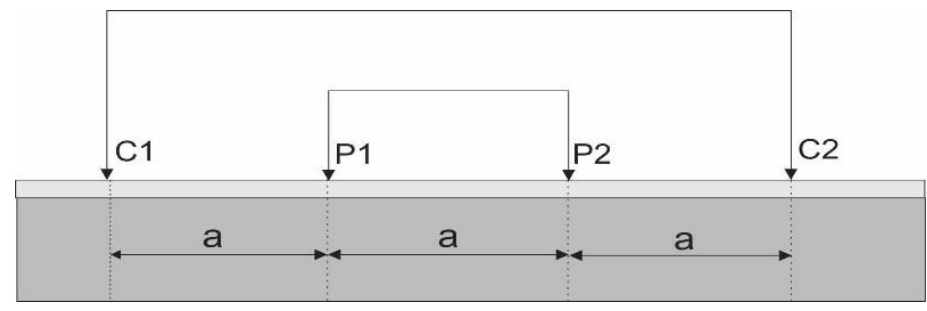

Gambar 1. Konfigurasi Wenner Alfa

Nilai resistivitas dapat dihitung melalui persamaan:

$$
\rho_{a}=2 \pi a \frac{\Delta \mathrm{V}}{\mathrm{I}}
$$

Nilai resistivitas setiap material berbeda-beda. Berikut ini adalah Tabel Resistivitas Material Geologi dari beberapa jenis material. 
Tabel 1. Resistivitas beberapa Material Geologi ${ }^{[6][7][8]}$

\begin{tabular}{cccc}
\hline $\begin{array}{c}\text { Material } \\
\text { Resistivitas }(\Omega \mathrm{m})\end{array}$ & Resistivitas $(\Omega \mathrm{m})$ & $\begin{array}{c}\text { Material } \\
\text { Resistivitas } \\
(\Omega \mathrm{m})\end{array}$ & Resistivitas $(\Omega \mathrm{m})$ \\
\hline Air & $1-9$ & Andesit & $1,7 \times 102-4,5 \times 104$ \\
Lempung & $1-20$ & Basalt & $10-1,3 \times 107$ \\
Lempung basah & $10-35$ & Tuff & $2 \times 103-105$ \\
Lempung pasiran & $30-215$ & Kuarsa & $3 \times 102-106$ \\
Top Soil & $250-1700$ & Batu Pasir & $1-6,4 \times 108$ \\
\hline
\end{tabular}

\section{METODOLOGI}

Penelitian bidang gelincir longsor dengan metode geolistrik resistivitas ini dilaksanakan pada bulan Maret 2016 sampai Juni 2016. Lokasi pengambilan data penelitian adalah Dusun Dukuh, Desa Koripan, Kecamatan Matesih, Kabupaten Karanganyar.

Terdapat 5 lintasan pengambilan data. Tiga buah lintasan terletak sejajar dari arah Selatan ke Utara, dan dua buah lintasan terletak sejajar dari arah Timur ke Barat. Masing-masing lintasan tersebut memiliki panjang $75 \mathrm{~m}$. Pengambilan data dilakukan dengan spasi elektroda terkecil yaitu 3 meter, dengan faktor pengali (n) mulai dari 1 sampai dengan 5 pada semua lintasan uji.

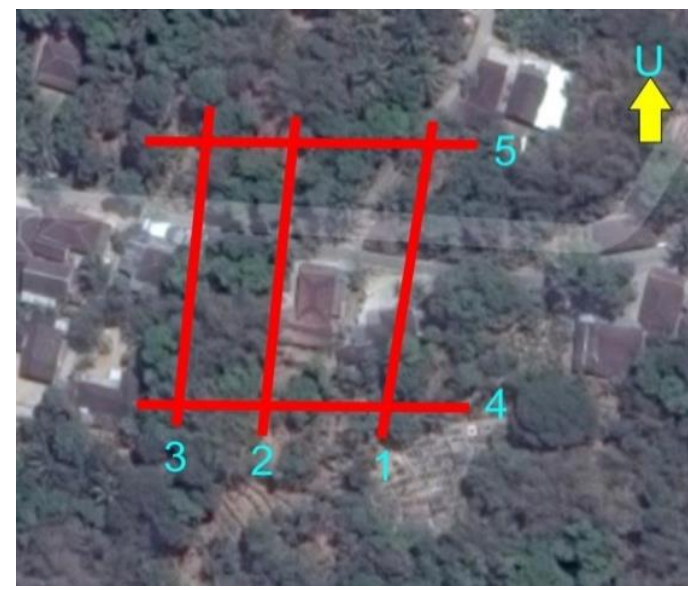

Gambar 2. (Colour Online) Lintasan Uji

Pengambilan data resistivitas dilakukan menggunakan peralatan utama yaitu Resistvity Meter OYO tipe 2119C McOHM-EL Data kemudian diolah menggunakan software Res2Dinv dan diperoleh hasil inversi berupa gambar 2 dimensi yang menggambarkan kondisi bawah tanah. Selanjutnya pemodelan 3 dimensi dilakukan dengan Rockworks16 untuk mengetahui titik temu dari tiap lintasan dengan lintasan lain, dan juga untuk memprediksi daerah yang diduga memiliki potensi pergerakan tanah yang tinggi.

\section{HASIL DAN PEMBAHASAN}

\section{Lintasan 1}

Lintasan pertama terbentang dari arah Selatan ke Utara. Posisi elektroda pertama terletak pada posisi $7^{\circ} 39^{\prime} 57.91^{\prime \prime} \mathrm{LS}$ dan $111^{\circ} 4^{\prime} 11.08^{\prime \prime} \mathrm{BT}$, sedangkan elektroda terakhir terletak pada $7^{\circ} 39^{\prime} 55.76$ "LS dan $111^{\circ} 4^{\prime} 11.08^{\prime \prime}$ BT. Variasi ketinggian titik-titik pemasangan elektroda 
yaitu antara $606 \mathrm{~m}$ sampai $620 \mathrm{~m}$. Posisi elektroda tertinggi terletak di sebelah Selatan. Sedangkan posisi elektroda terendah terletak di sebelah Utara.

Berdasarkan data hasil inversi, lintasan 1 memiliki sebaran resistivitas antara 0,48 $\Omega \mathrm{m}$ sampai dengan $72,45 \Omega \mathrm{m}$. Lapisan yang ditandai dengan warna biru memiliki resistivitas antara $0,48 \Omega \mathrm{m}$ sampai dengan $8,97 \Omega \mathrm{m}$, diinterpretasikan sebagai lapisan lempung. Sedangkan lapisan dengan warna kuning sampai hijau, memiliki resistivitas antara $8,99 \Omega \mathrm{m}$ sampai $13,4 \Omega \mathrm{m}$, diinterpretasikan sebagai lapisan lempung basah. Lapisan dengan warna cokelat sampai dengan ungu kehitaman memiliki nilai resistivitas antara $13,5 \Omega \mathrm{m}$ sampai dengan $72,46 \Omega \mathrm{m}$, diinterpretasikan sebagai lapisan lempung basah sampai lempung pasiran.

Lapisan lempung basah dengan resistivitas antara $8,99 \Omega \mathrm{m}$ sampai $13,4 \Omega \mathrm{m}$, diduga bersifat kedap air pada bagian bawahnya, sehingga air akan terkumpul di permukaannya. Dengan demikian, permukaan lapisan tersebut menjadi lembek dan licin. Lapisan tersebut dianggap sebagai lapisan bidang gelincir lintasan 1.

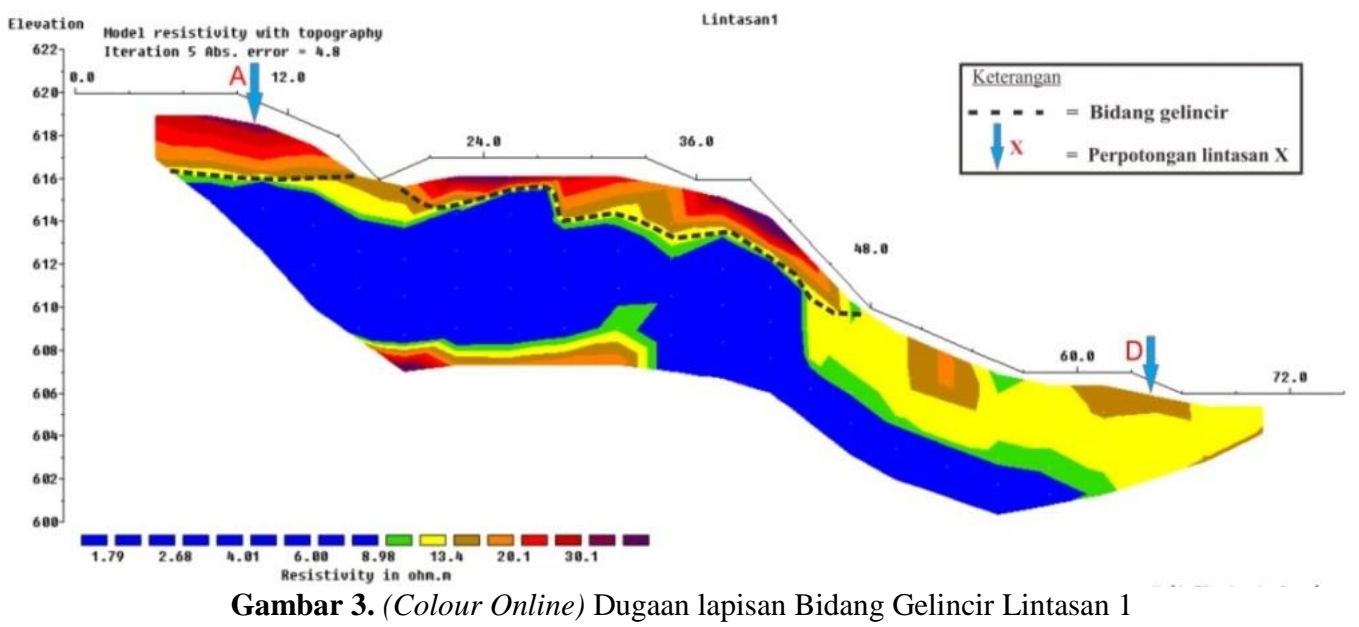

Lapisan bidang gelincir tersebut berada pada posisi 4,5 meter sampai 48 meter pada lintasan uji, dengan kedalaman antara 1 meter sampai 3,7 meter. Bentuk bidang gelincir adalah tidak teratur, sehingga jenis longsor yang dapat terjadi di daerah tersebut yaitu longsor bertingkat.

\section{Lintasan 2}

Terbentang dari arah Selatan ke Utara. Elektroda pertama terletak pada koordinat $7^{\circ} 39^{\prime} 57.91$ "LS dan $111^{\circ} 4^{\prime} 10.40^{\prime \prime}$ BT, dan posisi elektroda terakhir ada pada posisi $7^{\circ} 39 ' 55.76^{\prime \prime}$ LS dan $111^{\circ} 4^{\prime} 10.40^{\prime \prime}$ BT. Titik-titik pemasangan elektroda terdapat pada ketinggian antara $604 \mathrm{~m}$ sampai $619 \mathrm{~m}$. Posisi elektroda tertinggi terletak di sebelah Selatan.

Nilai resistivitas di bawah lintasan 2 berada pada rentang 1,52 $\Omega \mathrm{m}$ sampai 53,19 $\Omega \mathrm{m}$. Pada bagian paling bawah atau yang ditandai dengan warna biru, memiliki nilai resistivitas antara 1,52 $\Omega \mathrm{m}$ sampai $8,98 \Omega \mathrm{m}$, diinterpretasikan sebagai lapisan lempung. Lapisan dengan warna kuning sampai hijau memiliki resistivitas antara $8,99 \Omega \mathrm{m}$ sampai $13,4 \Omega \mathrm{m}$, diinterpretasikan sebagai lapisan lempung basah. Sedangkan lapisan dengan warna cokelat sampai ungu kehitaman memiliki resistivitas bervariasi antara $13,5 \Omega \mathrm{m}$ sampai $53,19 \Omega \mathrm{m}$, diduga merupakan lapisan lempung basah sampai lempung pasiran.

Lapisan lempung basah dengan resistivitas antara 8,99 $\Omega \mathrm{m}$ sampai $13,4 \Omega \mathrm{m}$ diduga merupakan lapisan bidang gelincir lintasan 2. Sifat lapisan tersebut lembek dan licin. 


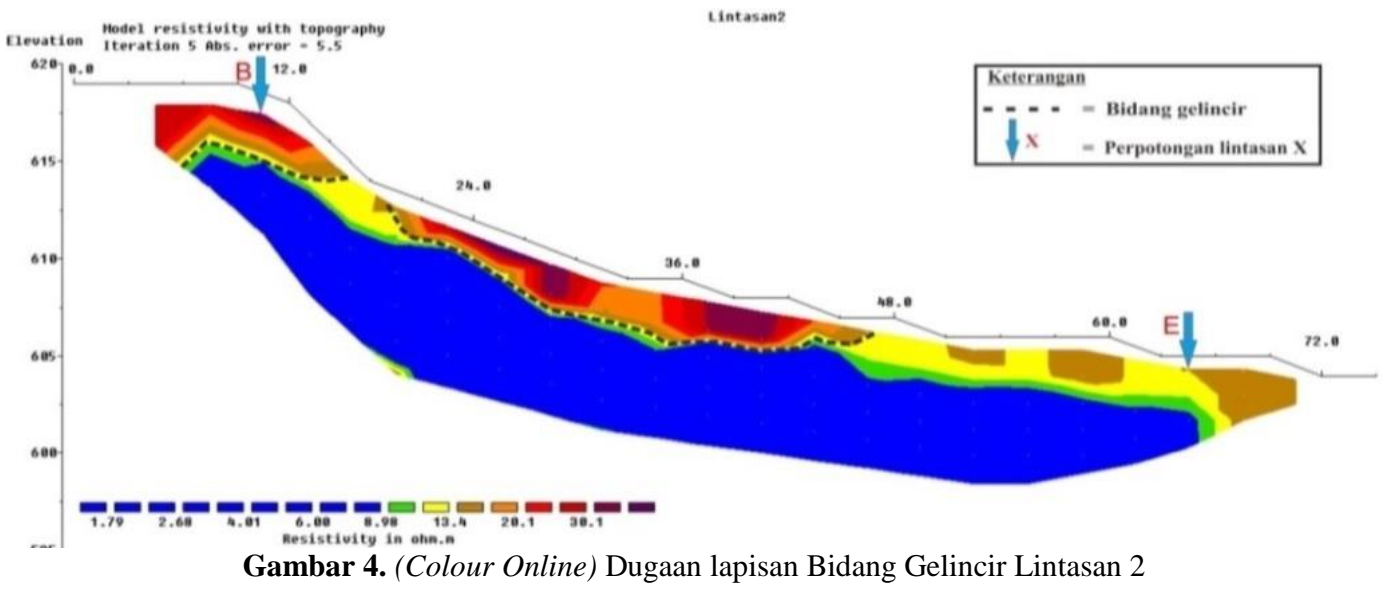

Bidang gelincir tersebut berada pada kedalaman 2 meter sampai 4 meter. Bentuk bidang gelincir lintasan 2 berupa cekungan, sehingga longsor yang dapat terjadi di daerah tersebut adalah longsor tipe rotasional.

\section{Lintasan 3}

Lintasan 3 terbentang dari arah Selatan ke Utara. Elektroda pertama terletak pada koordinat $7^{\circ} 39^{\prime} 57.91 " L S$ dan $111^{\circ} 4^{\prime} 10.04 " B T$, sedangkan posisi elektroda terakhir terletak pada koordinat $7^{\circ} 39^{\prime} 55.76 " \mathrm{LS}$ dan $111^{\circ} 4^{\prime} 10.04 " \mathrm{BT}$. Elevasi atau ketinggian tiap titik elektroda cukup bervariasi, antara 604 meter sampai 618 meter. Posisi titik tertinggi terletak di ujung Selatan pada lintasan.

Berdasarkan hasil inversi, resistivitas di bawah lokasi uji memiliki nilai antara $0,36 \Omega \mathrm{m}$ sampai $75 \Omega \mathrm{m}$.. Nilai resistivitas antara $0,36 \Omega \mathrm{m}$ sampai $8,98 \Omega \mathrm{m}$ atau yang ditandai dengan warna biru, diduga merupakan lapisan lempung. Lapisan dengan warna cokelat sampai ungu kehitaman, memiliki resistivitas antara $13,5 \Omega \mathrm{m}$ sampai $75 \Omega \mathrm{m}$, diduga sebagai lapisan lempung basah dan lempung pasiran.

Lapisan dengan warna hijau sampai kuning, memiliki resistivitas antara $8,99 \Omega \mathrm{m}$ sampai $13,4 \Omega \mathrm{m}$, diduga merupakan lapisan lempung basah yang bersifat lembek dan licin. Lapisan tersebut diduga merupakan bidang gelincir di bawah lintasan 3 .

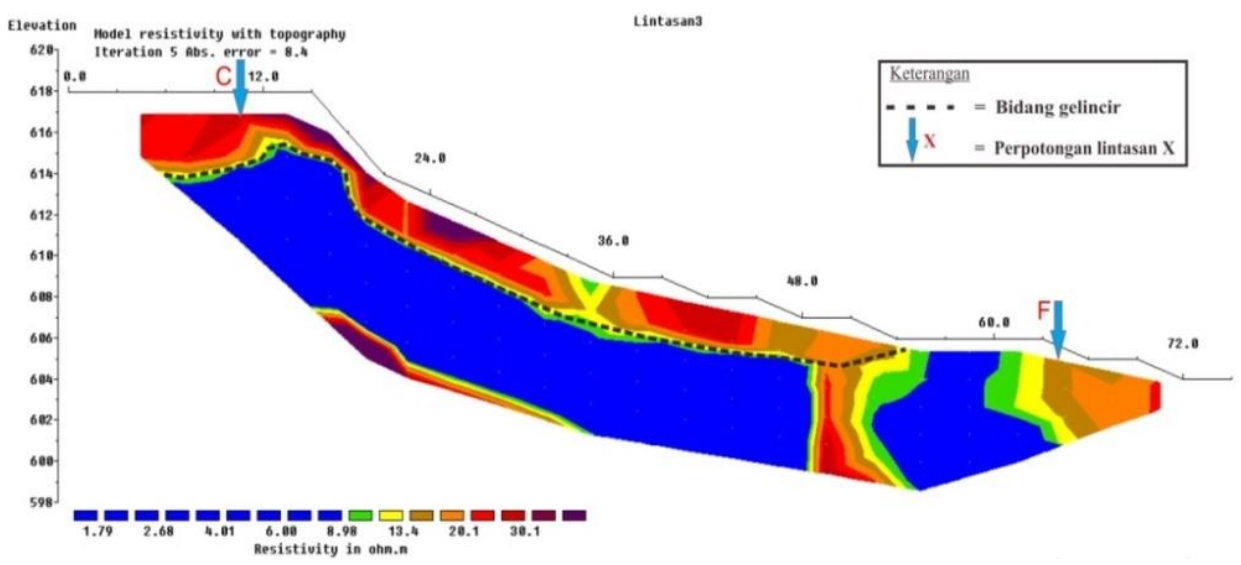

Gambar 5. (Colour Online) Dugaan lapisan Bidang Gelincir Lintasan 3

Lapisan bidang gelincir tersebut memanjang dari titik 4,5 meter sampai 54 meter pada lintasan. Lapisan tersebut berada pada kedalaman mulai dari 0,75 meter sampai 3,78 meter. 
berdasarkan bentuk bidang gelincirnya, jenis tanah longsor yang terjadi di daerah tersebut adalah jenis longsor rotasional.

\section{Lintasan 4}

Terletak pada posisi $7^{\circ} 39^{\prime} 57.71$ "LS dan $111^{\circ} 4^{\prime} 11.87^{\prime \prime B T ~ s a m p a i ~ d e n g a n ~} 7^{\circ} 39^{\prime} 57.71 " L S$ dan $111^{\circ} 4^{\prime} 9.71 " B T$. Terbentang dari arah Timur ke Barat. Ketinggian tiap titik elektroda yaitu antara $615 \mathrm{~m}$ sampai $622 \mathrm{~m}$.

Data hasil inversi menunjukkan bahwa resistivitas di bawah lintasan 4 cukup bervariasi. Nilai resistivitas lapisannya antara $0,54 \Omega \mathrm{m}$ sampai $59,93 \Omega \mathrm{m}$. Untuk lapisan dengan nilai resistivitas antara $0,54 \Omega \mathrm{m}$ sampai $8,98 \Omega \mathrm{m}$, disimbolkan dengan warna biru diinterpretasikan sebagai lapisan lempung. Lapisan dengan warna cokelat sampai ungu kehitaman memiliki resistivitas antara 14,5 $\Omega \mathrm{m}$ sampai 59,93 $\Omega \mathrm{m}$, diduga merupakan lapisan lempung basah dan lempung pasiran.

Lapisan dengan nilai resistivitas 8,99 sampai 13,4 $\Omega \mathrm{m}$, disimbolkan dengan warna hijau sampai kuning. Lapisan tersebut diduga merupakan lapisan bidang gelincir di lokasi tersebut.

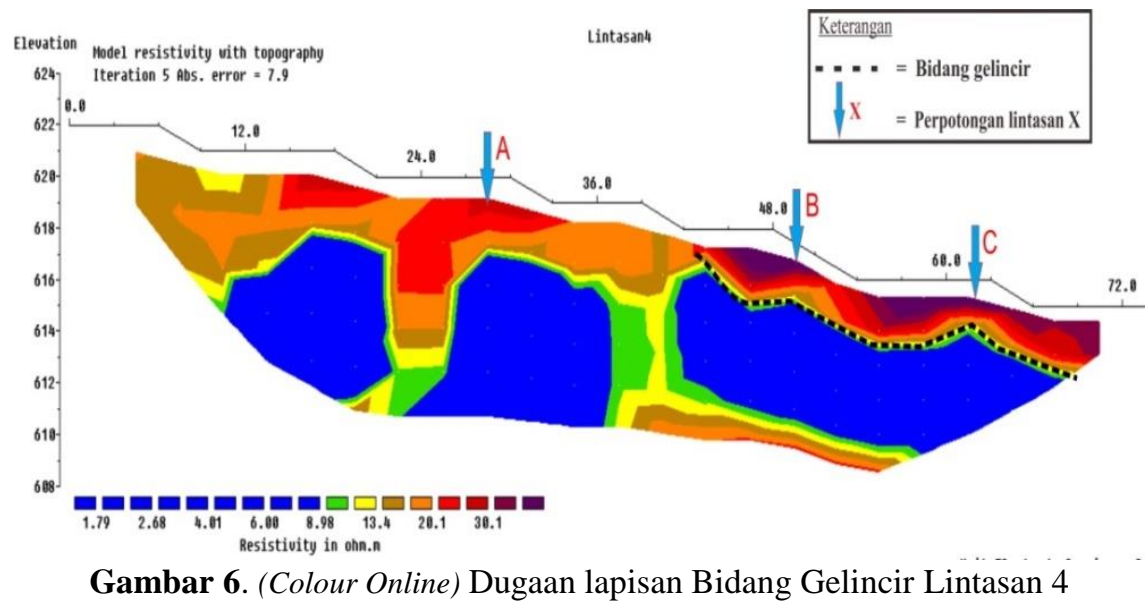

Bidang gelincir tersebut berada pada kedalaman 1,5 meter sampai 3,5 meter. Bentuk bidang gelincir yaitu tidak teratur, sehingga dugaan longsor yang terjadi di lokasi tersebut yaitu longsor bertingkat.

\section{Lintasan 5}

Terletak sejajar dengan lintasan 4, yaitu dari arah Timur ke Barat. Elektroda pertama terletak pada posisi $7^{\circ} 39^{\prime} 55.95^{\prime \prime} \mathrm{LS}$ dan $111^{\circ} 4^{\prime} 11.87 " \mathrm{BT}$, sedangkan elektroda terakhir terletak pada posisi $7^{\circ} 39^{\prime} 55.95 " \mathrm{LS}$ dan $111^{\circ} 4^{\prime} 9.71^{\prime \prime} \mathrm{BT}$. Ketinggian tiap titik elektroda bervariasi, antara $602 \mathrm{~m}$ sampai $611 \mathrm{~m}$. Posisi tertinggi terletak di sisi Timur dari lintasan.

Berdasarkan data hasil inversi, nilai resistivitas di bawah lokasi uji bervariasi, mulai dari 0,6 $\Omega \mathrm{m}$ sampai $65,37 \Omega \mathrm{m}$. Lapisan dengan resistivitas antara $0,6 \Omega \mathrm{m}$ sampai $8,98 \Omega \mathrm{m}$ ditandai dengan warna biru, diduga merupakan lapisan lempung basah. Sedangkan lapisan dengan resistivitas $14,5 \Omega \mathrm{m}$ sampai $65,37 \Omega \mathrm{m}$, disimbolkan dengan warna cokelat sampai ungu kehitaman. Lapisan tersebut diduga merupakan lapisan lempung basah sampai lempung pasiran. 
Lapisan dengan resistivitas $8,99 \Omega \mathrm{m}$ sampai $14,4 \Omega \mathrm{m}$, disimbolkan dengan warna kuning sampai hijau. Lapisan tersebut diduga tersusun dari material lempung basah yang lembek dan licin. Lapisan dengan sifat demikian dianggap sebagai lapisan bidang gelincir di lintasan 5 .

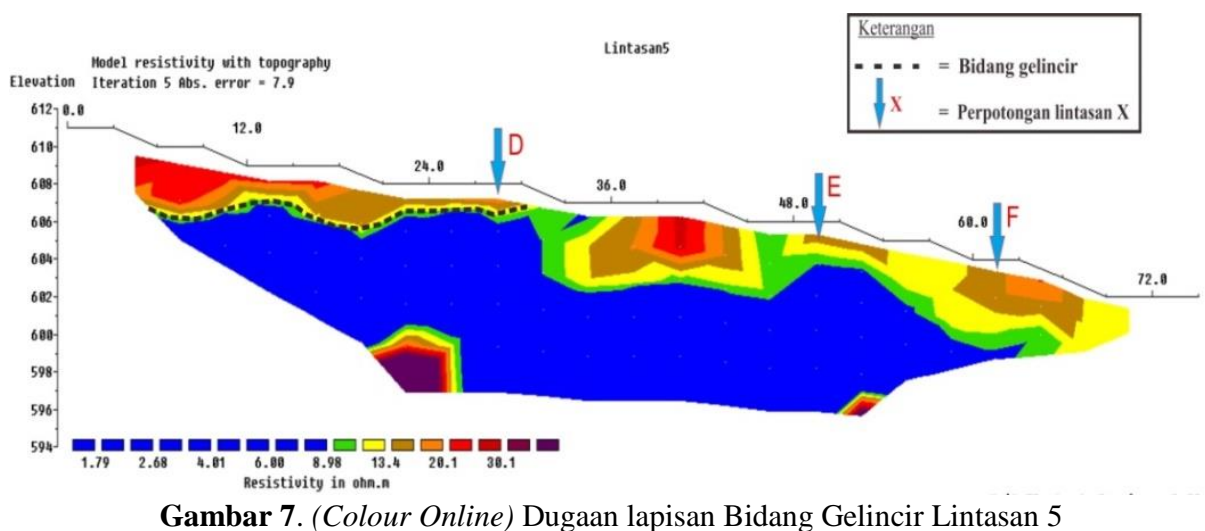

Kedalaman bidang gelincir tersebut antara antara 0,75 meter sampai 3 meter. Bentuk bidang gelincir berdasarkan gambar 4.10 yaitu tidak teratur, sehingga tipe longsor yang terjadi yaitu longsor bertingkat.

\section{Model 3 Dimensi}

Pemodelan 3 dimensi dilakukan dengan menggunakan perangkat lunak Rockworks16. Input yang dimasukkan ke dalam Rockworks16 berasal dari data hasil inversi Res2Dinv. Data tersebut berupa posisi datum X, kedalaman titik, dan nilai resistivitas dari titik tersebut. Selain itu, data lain yang diperlukan yaitu data posisi (Easting dan Northing), dan elevasi yang diperoleh dari survei lapangan.

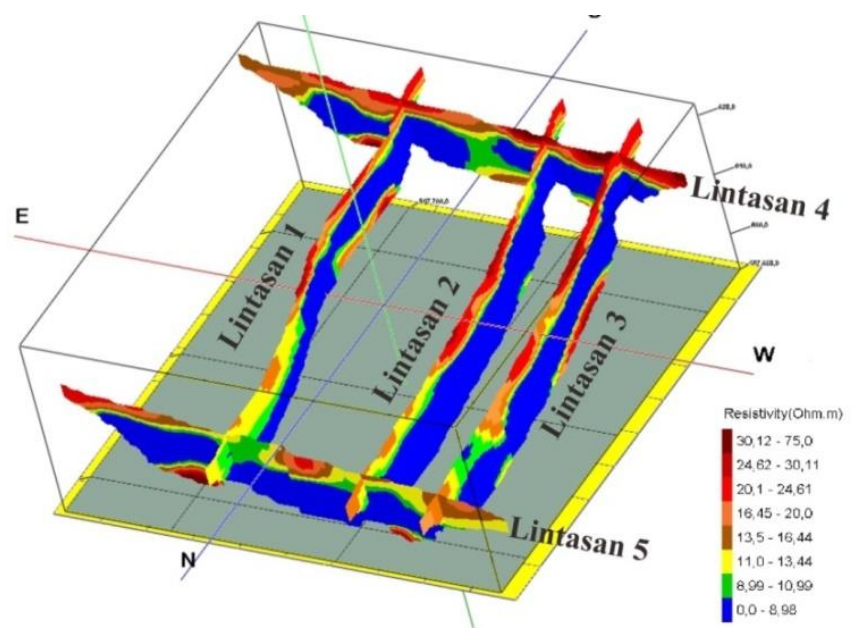

Gambar 8. (Colour Online) Perpotongan Lintasan dengan Model Fence

Dari pemodelan di atas, dapat dilihat posisi dari masing-masing lintasan uji serta perpotongan antar lintasan uji. Berdasarkan perpotongan pada gambar tersebut, dapat diketahui bahwa terdapat korelasi nilai resistivitas pada titik pertemuan lintasan. Titik tertinggi pada lokasi penelitian, terletak pada sisi sebelah Tenggara (Southeast). Sedangkan titik terendah terletak pada sisi sebelah Barat Laut (Northwest). 
Selanjutnya dilakukan pemodelan dengan bentuk solid. Dengan meninjau kembali posisi bidang gelincir pada gambar 2D hasil inversi Res2Dinv, maka dilakukan pendugaan daerahdaerah yang rawan terjadi pergerakan lapisan longsoran. Berikut ini pendugaan daerah rawan pergerakan tanah dan longsor, hasil korelasi antara hasil 2D dan 3D solid.

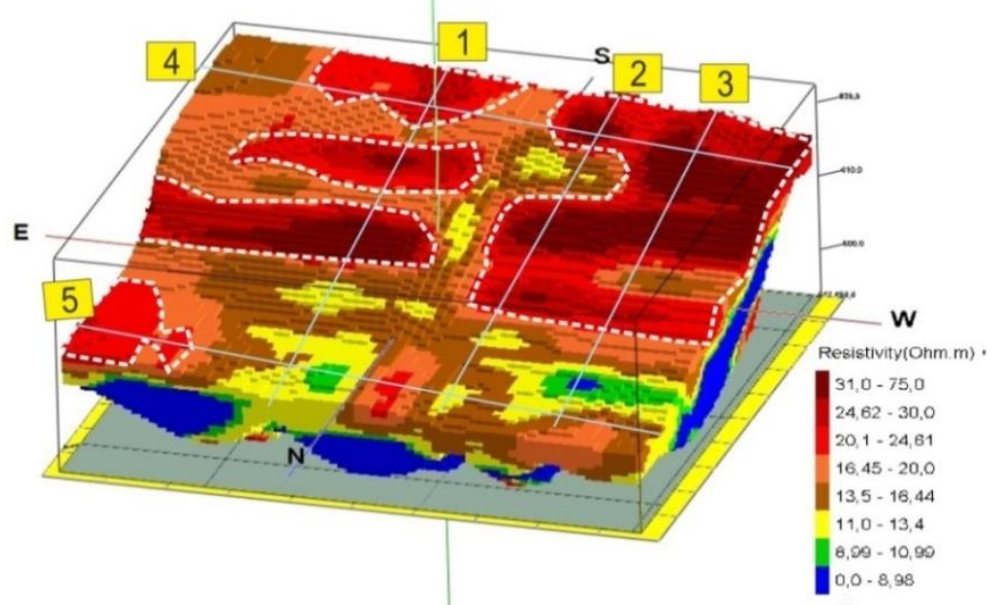

Gambar 9. (Colour Online) Daerah Rawan Pergerakan Tanah

Garis biru muda pada gambar di atas menunjukkan lintasan pengambilan data. Daerah yang dibatasi dengan garis putih putus-putus, merupakan daerah yang diduga memiliki potensi pergerakan tanah yang tinggi. Daerah tersebut memiliki material penyusun berupa lempung basah sampai lempung pasiran.

\section{KESIMPULAN}

1. Struktur lapisan tanah di lokasi penelitian terbentuk dari 3 lapisan utama, yaitu lapisan bagian atas atau lapisan material longsoran, lapisan bidang gelincir, dan lapisan bagian bawah. Lapisan atas tersusun dari material lempung pasiran, dan lempung basah. Pada bagian ini terdapat banyak akuifer air sehingga lapisan tersebut dapat menyimpan dan menyalurkan air. Sedangkan lapisan bidang gelincir tersusun dari material lempung basah yang kedap air pada bagian bawahnya, dan bersifat lembek dan licin pada permukaannya. Dan lapisan bagian bawah merupakan material lempung. Pada lapisan tersebut hanya terdapat sedikit air karena rapatnya lapisan tersebut.

2. Tiap lintasan uji memiliki bidang gelincir dengan karakteristik yang berbeda. Berikut informasi bidang gelincir dari masing-masing lintasan.

\begin{tabular}{cccc}
\hline Lintasan Uji & $\begin{array}{c}\text { Kedalaman } \\
\text { Bidang gelincir }(\mathrm{m})\end{array}$ & $\begin{array}{c}\text { Bentuk Bidang } \\
\text { Gelincir }\end{array}$ & Tipe Longsor \\
\hline 1 & $1-3,7$ & Tidak teratur & Bertingkat \\
2 & $2-4$ & Cekungan & Rotasional \\
3 & $0,75-3,78$ & cekungan & Rotasional \\
4 & $1,5-3,5$ & Tidak teratur & Bertingkat \\
5 & $0,75-3$ & Tidak teratur & Bertingkat \\
\hline
\end{tabular}

3. Daerah dengan pergerakan tanah yang tinggi dapat di identifikasi dari keberadaan lapisan longsoran dengan lapisan penutup berupa lempung pasiran dan lempung basah. Sifat lempung tersebut yaitu dapat meloloskan air sampai ke lapisan bidang gelincir. 
Dengan masuknya air ke bidang gelincir tersebut, maka permukaan bidang gelincir menjadi lebih licin. Hal tersebut yang memperbesar kemungkinan terjadinya pergerakan tanah di lokasi tersebut.

\section{DAFTAR PUSTAKA}

1 Highland, L., \& Bobrowsky, P. (2008). The landsline handbook-A guide to understanding landslide. Reston, Virginia: U.S. Geological Sevey Circular.

2 BNPB. (2015). Data dan informasi bencana indonesia BNPB. Dipetik Desember 12, 2015, dari http://dibi.bnpb.go.id/DesInventar/dashboard.jsp

3 Darsono, Nurlaksito, B., \& Legowo, B. (2012). identifikasi bidang gelincir pemicu bencana tanah longsor dengan metode resistivitas 2 dimensi di desa pablengan kecamatan matesih kabupaten karanganyar. Indonesia Journal of Applied Physics, vol 2, 57-66.

4 Bari, C. d., Lapenna, V., Perrone, A., Puglisi, C., \& Sdao, F. (2011). Digital photogrammetric analysis and electrical resistivity tomography for investigating the Picerno landslide (Basilicata region, southern Italy). Geomorphology, 133; 34-40.

5 Iqbal, M., \& Budiman, A. (2013). Investigasi Bidang Gelincir Pada Lereng Menggunakan Metode Geolistrik Tahanan Jenis Dua Dimensi (Studi Kasus: Kelurahan Lumbung Bukit Kecamatan Pauh Padang). Jurnal Fisika Unand. Vol. 2, No. $2,88-93$.

6 Telford, W. M., Geldart, L., \& Sheriff, R. E. (1990). Applied Geophysics 2nd Edition. Cambridge: Cambridge University Press.

7 Reynolds, J. M. (1997). An Introduction to Applied and Environtmental Geophysics. Chichester: John Wiley \& Sons.

8 Lesmana, H., \& Subagiada, K. (2016). Identifikasi Basement Rock pada zona longsoran dengan menggunakan metode geolistrik (studi kasus wilayah kelurahan Selili kecamatan Samarinda Ilir Kota Samarinda, Kalimantan Timur). Prosiding Seminar Sains dan Teknologi FMIPA UNMUL, VOL 1, hal 32-36. 